\title{
Autoimmune Process
}

National Cancer Institute

\section{Source}

National Cancer Institute. Autoimmune Process. NCI Thesaurus. Code C16313.

A specific humoral or cell-mediated immune response against autologous (self) antigens. An autoimmune process may produce or be caused by autoimmune disease and may be developmentally complex, not necessarily pathological, and possibly pervasive. 